\title{
A novel bacteriophage with broad host-range against Clostridioides difficile ribotype 078 elucidates the phage receptor
}

3

4

5

6

M.J Whittle ${ }^{1}$, T.W Bilverstone ${ }^{1}$, R.J van Esveld ${ }^{3}$, A.C. Lücke ${ }^{4}$, M.M Lister ${ }^{1,2,5}$, S.A Kuehne 1,2,6 and N.P Minton ${ }^{1,2 *}$

7

\section{Corresponding author: nigel.minton@nottingham.ac.uk}

Keywords: Bacteriophage, phage therapy, Clostridioides difficile (Clostridium difficile), Slayer, SIpA.

\section{Current Address:}

5Department of Clinical Microbiology, Queen's Medical Centre, Nottingham University Hospitals NHS Trust, Nottingham, UK, UK,

${ }^{6}$ Oral Microbiology Group, School of Dentistry and Institute of Microbiology and Infection, UK. 


\section{Abstract:}

Bacteriophage represent a promising option for the treatment of Clostridioides difficile (formerly Clostridium difficile) infection (CDI), which at present relies on conventional antibiotic therapy. The specificity of bacteriophages should prevent the dysbiosis of the colonic microbiota associated with the treatment of CDI with antibiotics. Whilst numerous phages have been isolated, none have been characterised with broad host-range activity towards PCR ribotype (RT) 078 C. difficile strains despite their considerable relevance to medicine and agriculture. In this study, we isolated four novel C. difficile Myoviruses: ФCD08011, ФCD418, ФCD1801 and ФCD2301. Their characterisation revealed that each was comparable with other $C$. difficile phages described in the literature, with the exception of $\Phi C D 1801$ which exhibited a broad host-range activity towards RT 078, infecting 15/16 $(93.8 \%)$ of the clinical isolates tested. In order for wild-type phages to be exploited in the effective treatment of CDI, an optimal phage cocktail must be assembled that provides broad coverage against all $C$. difficile RTs. In an attempt to advance these efforts, we conducted a series of fundamental experiments that identified the C. difficile SIpA, the major constituent of the $C$. difficile surface-layer (S-layer), as the phage receptor. Thus, we demonstrated that $\Phi C D 1801$ could only bind to RT 012 or RT 027 strains in the presence of a plasmid-borne S-layer cassette corresponding to RT 078. Armed with this information, efforts should now be directed towards the isolation of phages with broad host-range activity against each of the fourteen described S-layer cassette types which could form the basis of an effective cocktail active against a wide range of $C$. difficile isolates. 


\section{Importance:}

58 Research into phage therapy has seen a resurgence in recent years owing to growing 59 concerns regarding antimicrobial resistance. Phage research for potential therapy against 60 Clostridium difficile infection (CDI) is in its infancy, where an optimal "one size fits all" 61 phage cocktail is yet to be derived. The pursuit thus far, has aimed to find phages with the broadest possible host-range. Although, for $C$. difficile strains belonging to certain PCR ribotypes (RTs), in particular RT 078, phages with broad-host range activity are yet to be

64 discovered. In this study, we isolate 4 novel Myoviruses including $\Phi C D 1801$, which exerts the broadest host-range activity towards RT 078 reported in the literature. Through the application of $\Phi C D 1801$ to robust binding assays, we elucidate SIpA as the phage receptor on the bacterial cell surface. Our finding suggests that an optimal "one size fits all" combinatorial phage cocktail, could theoretically comprise 14 phages, each targeting one of the 14 described S-layer cassettes of $C$. difficile. 


\section{Introduction:}

Clostridioides difficile (formerly Clostridium difficile [1]) is the leading cause of hospitalassociated diarrhoea in the developed world, responsible for up to 29,000 deaths per annum in the USA [2]. C. difficile infection (CDI) ensues from dysbiosis of the gut microbiota, in response to broad-spectrum antibiotic treatment [3]. Up to $65 \%$ of patients suffer recurrent infection or relapse, following treatment of CDI with metronidazole or vancomycin [4]. This phenomenon is a consequence of the spore-forming nature of $C$. difficile, concomitant with the reduced-diversity microbiota following sustained antibiotic therapy [5]. This unfortunate chain of circumstance, whereby the antibiotic for the treatment of CDI, is also the predisposing risk factor for its contraction, calls for a more directed approach to combatting this infection. An approach that minimally disrupts the diversity of the gut microbiota.

Bacteriophages (phages) are generally considered as narrow host-range viruses, where host specificity can be observed at the genus, species or sub-species level [6]. Consequently, bacteriophage might represent an appropriate narrow-spectrum therapy for the treatment of CDI. To-date, many phages infecting $C$. difficile have been characterised, all of which, are temperate Myoviridae/Siphoviridae belonging to the Caudovirales order of phages. However, no phage has been described with broad host-range activity towards PCR ribotype 078 (RT 078), strains of which are of considerable clinical and agricultural relevance [7].

Whilst the efficacy of single-phage therapy has little remedial effect in vivo, combinatorial therapy has demonstrated some merit. Therein, a cocktail of phages was able to delay the time to end-point by almost $100 \%$ in hamsters infected with one strain of $C$. difficile [8]. These promising data warrant further study into optimal phage cocktail combinations.

The efforts towards combinatorial phage cocktails would be considerably boosted, had the phage receptor on the surface of the bacterial cell, been identified. Although two research 
102

103

104

105

106

107

108

109

110

111

112

113

114

115

116

117

118

119

120

121

122

123

124

125

126

127

128

129

130

131

132

133

134

articles have suggested that the surface layer (S-layer) constituent, SIpA, represents the likely phage receptor candidate $[9,10]$, there exists a lack of experimental evidence to verify the crucial relationship between the infecting bacteriophage and the identity of the host S-layer.

In this study, we isolated and characterised four novel bacteriophages, one of which, ФCD1801, possessed broad host-range activity against C. difficile PCR ribotype 078 (RT 078). Through the plasmid-borne expression of RT 078 S-layer cassettes in RT 012 and RT 027 strains, we were able to demonstrate cross-ribotype binding, thus affirming SIpA, as the phage receptor for $C$. difficile.

\section{$\underline{\text { Results and Discussion }}$}

\section{Isolation and visualisation of four novel Myoviruses.}

We sought to isolate phages with infective capacity towards RT 078 . RT 078 strains are often considered potentially-hypervirulent [11]. Indeed, strains possess the binary toxin genes ( $C$. difficile Transferase, CDT), whilst their clinical presentation is comparable to that of the notorious RT 027 [12]: the hypervirulent ribotype responsible for severe outbreaks across North America and Europe [13]. To enhance our efforts, we obtained a library of clinical isolates from CDI-positive patients at the Queens Medical centre (Nottingham, UK), which included eight novel RT 078 isolates (See Table S1 for novel strains described in this article). Using CD1801 as an isolation host, we were able to isolate ФCD1801 from an anaerobic digester sample derived from the Stoke Bardolph sewage treatment plant (Nottinghamshire, UK). In parallel, we isolated ФCD08011, ФCD2301 and ФCD522418 (hereafter referred to as ФCD418) from RT 002, 014 and 023 hosts, respectively. 
135 TEM analysis revealed that $\Phi C D 418, \Phi C D 2301$ and $\Phi C D 1801$ possessed contractile tails

136 (Fig. 1a-c), suggesting they belonged to the Caudovirales order of tailed phages and were,

137 like most of the published C. difficile phages, Myoviruses. Indeed, the tail and capsid

138 measurements are in-line with those previously reported for C. difficile Myoviruses [14,

139 15]. The imaging results were less clear for $\Phi C D 08011$. Wherein, after multiple

140 experiments, phage particles always appeared with contracted tails and empty capsids

141 indicative of DNA release (Fig. 1d). In light of these issues, we are unable to definitively

142 state that $\Phi C D 08011$ is a member of the Myoviridae family.

143 
bioRxiv preprint doi: https://doi.org/10.1101/2021.05.26.445907 this version posted May 29, 2021. The copyright holder for this preprint (which was not certified by peer review) is the author/funder, who has granted bioRxiv a license to display the preprint in perpetuity. It is made available under aCC-BY 4.0 International license.

a)

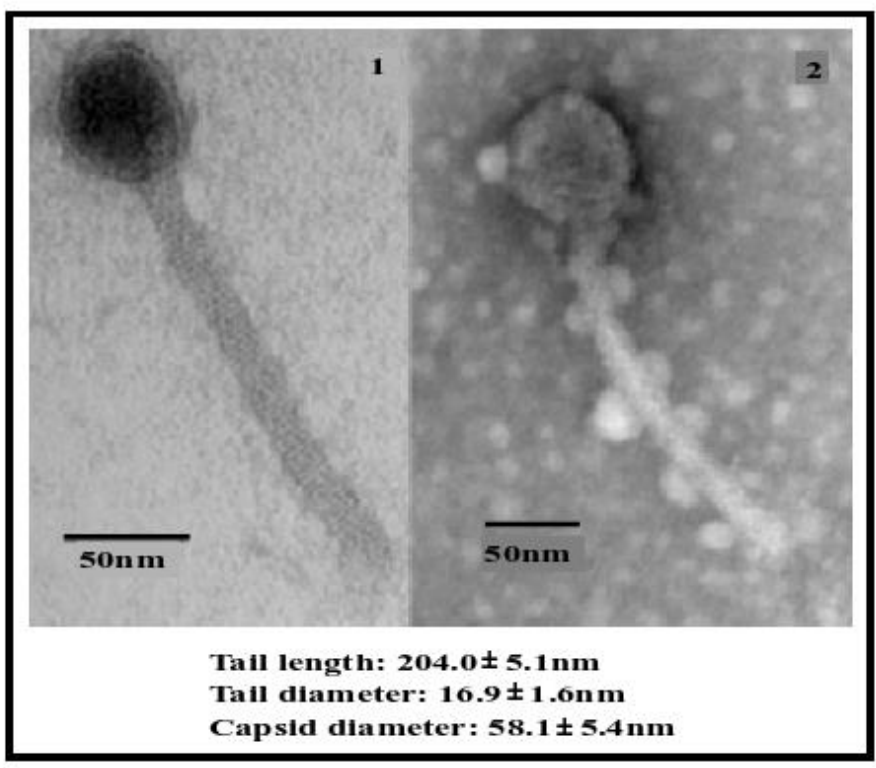

c)

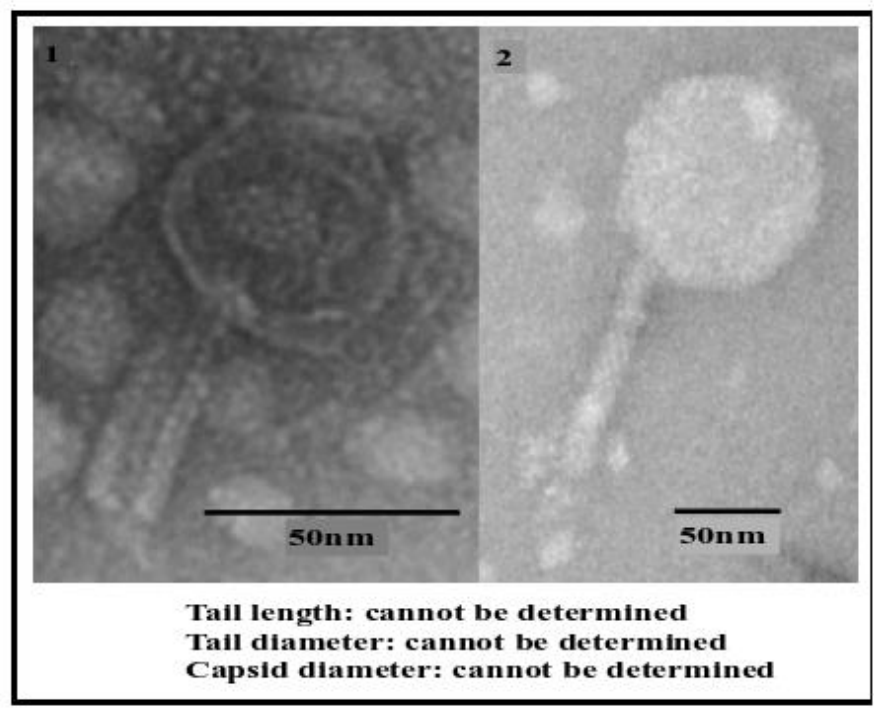

b)

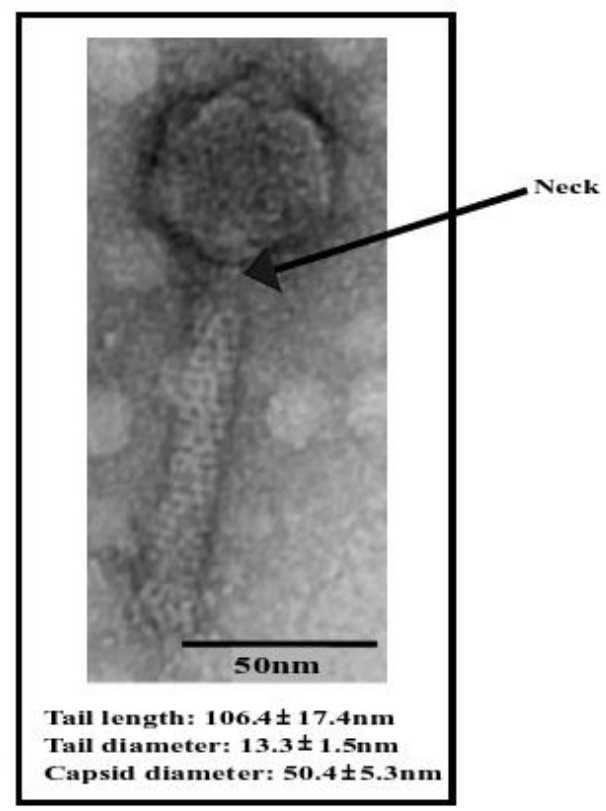

d)

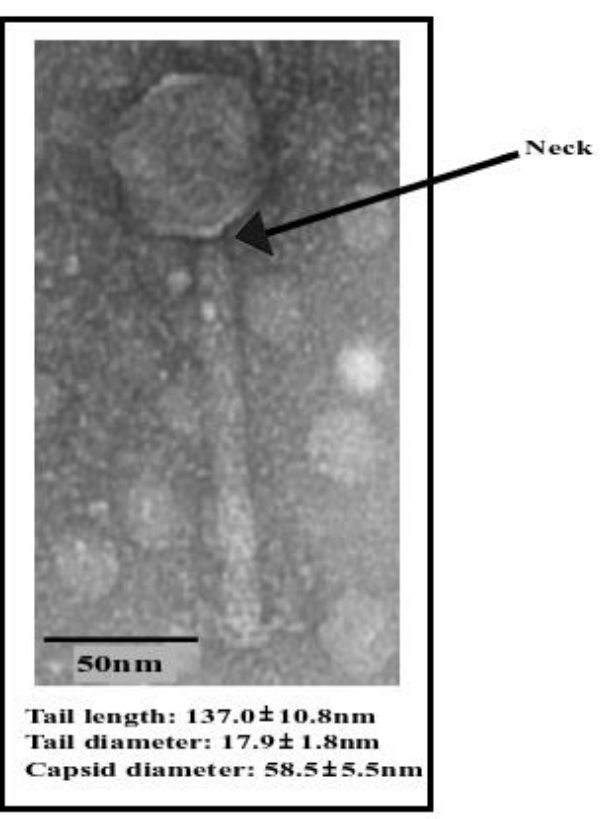

Figure 1: Phage particle morphology as visualised using TEM. for a) $\Phi C D 418$; b) $\Phi C D 2301$; phage particles. 
149 Phage genome sequencing, annotation and analysis

150 Full genome sequencing of $\Phi C D 1801$ followed by de novo assembly, revealed a 44,363bp circular genome with a GC content of $28.87 \%$. Artemis software predicted the genome to contain 50 ORFs, of which putative function could be assigned to 32. A graphical representation of the $\Phi C D 1801$ genome is provided in Fig. 2a. A lytic repressor protein (CD1801_gp35) was annotated by sequence alignment with repressor proteins derived from other published $C$. difficile phage sequences using the EMBOSS pairwise sequencealignment tool [16]. Doing so, unveiled $100 \%$ amino acid similarity with the repressor protein in C. difficile phage $\Phi C D 27$ [17]. A head connector protein (CD1801_gp8) was also located within the genome, further confirming the classification of ФCD1801 as a Myovirus. The genome was closed via PCR with primers annealing to the left and right flanks of the assembled contig. Primer sequences for the closure of phage genomes are provided in Table S2.

162

Using the abovementioned analyses, closed genome maps were generated for $\Phi$ CD08011 and $\Phi C D 418$ with genome lengths of 31,394 and 53,311bp, respectively (Fig. 2b-c). Both genomes comprised dsDNA with GC contents of $29.81 \%$ ( $(\mathrm{CD} 08011$ ) and $29.07 \%$ (ФCD418). A total of 35 ORFs were detected for $\Phi C D 08011$ of which 23 were assigned putative function, compared with 35 putative functional protein-coding genes, from a total of 58 for $\Phi C D 418$.

It was not possible to generate a closed genome for $\$ 2301$. Whilst the $38,695 \mathrm{bp}$ dsDNA genome could be assembled into one single contig, it was not possible to close the genome via PCR at the left and right flanks of the assembled reads, despite repeated attempts. As such, we present this genome as a linear fragment (Fig. 2d). A total of 39 ORFS were detected for $\$ 2301$ of which 27 could be assigned putative function. 
178 they are temperate. As integrase genes were identified at gp36 and gp37 for ФCD418 and

179 ФCD2301 respectively. These data are confounded by the generation of lysogens for each

180 of the four phages described herein.

181

182 In silico analysis revealed the presence of integrase genes in the genomes of all four 183 phages, corresponding to CD1801_gp33, CD08011_gp33, CD418_gp36 and 184 CD2301_gp37 for ФCD1801, ФCD08011, ФCD418 and ФCD2301, respectively. Their 185 presence suggests that all four are, in common with all previously isolated C. difficile 186 phage, temperate in nature. This conclusion was confirmed by the subsequent isolation 187 of $C$. difficile lysogens for each phage.

189 Annotated phage genomes were submitted to GenBank as a BankIt submission. The 190 accession numbers for each genome are as follows: ФCD1801 (MW512570); ФCD08011 (MW512572); ФCD418 (MW512573); and Ф2301 (MW512571).

a)



。



b)

d)
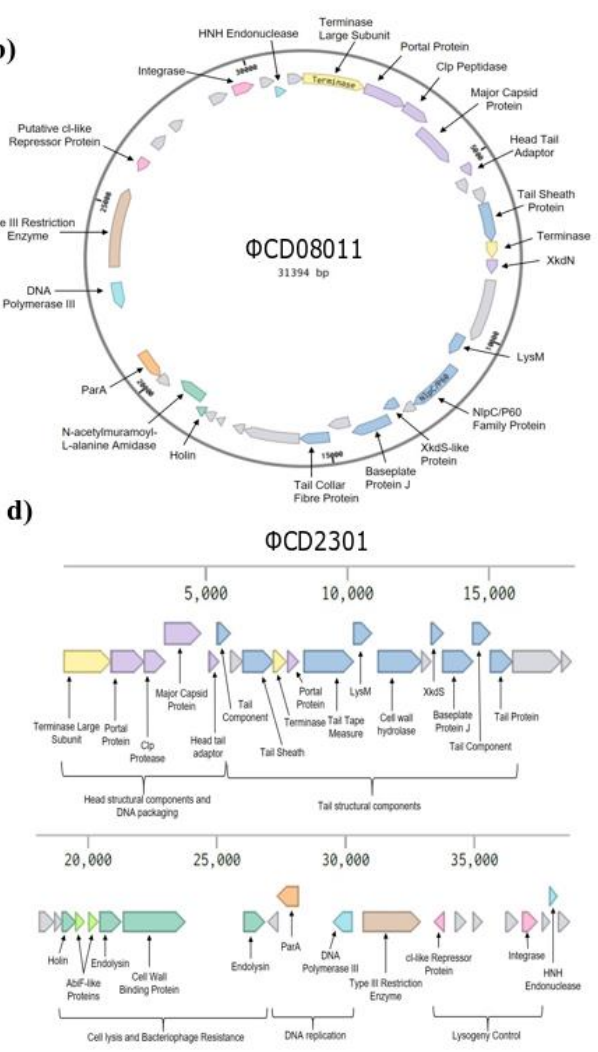
Figure 2: Graphical representation of phage genomes. a) $\Phi C D 1801$; b) $\Phi C D 08011$; c) ФCD418; and d) ФCD2301;.Assembled using CLC Genomics Workbench and manually annotated using Artemis, BLAST, UniProt and pfam. Notably, the genome contains an integrase gene indicating ФCD1801 is a temperate phage. Proteins encoding the capsid and tail including the base plate protein were identified.

\section{Phage host range testing}

201

Thus far, we had isolated four Myovirus phages that individually infect at least one RT 001, 014, 023 and 078 isolate. Genomic and phenotypic analysis thereof, suggests that the novel phages are comparable to other phages reported for $C$. difficile. Hitherto, there have been few phages characterised with infective capacity for RT 078. Most of which demonstrated very narrow host-ranges within the ribotype. For example, when a panel of seven phages were screened for their ability to infect eight RT 078 isolates, seven had no host-range coverage whatsoever, whilst one phage was able to infect $3 / 8$ strains, representing $38 \%$ host-range activity [8].

210 To determine the host-range coverage of our novel phages, we adopted a standard double agar overlay plaque assay (see Methods) on 162 clinical isolates of $C$. difficile of varying RTs. This analysis revealed that $\Phi C D 1801$ had broad host-range activity towards RT 078 .

213 Infection was observed for $15 / 16$ isolates with varying efficiencies of plating (see 214 experimental), representing 93.8\% coverage (Fig. 3). To our knowledge, these data 215 indicate that $\Phi C D 1801$ has the greatest reported host-range coverage within RT 078. To ascertain why our phage was unable to infect the resistant strain (CD2315), we analysed

217 the genome listing previously provided to NCBI by our research group (Accession 218 CP068554.1). Analysis using the PHASTER web tool [18], identified the presence of an 219 intact prophage. Further inspection by means of EMBOSS pairwise sequence analysis [17], uncovered $100 \%$ nucleotide identity between the lysogenic repressor protein of ФCD1801 and the prophage contained within the genome of CD2315. Taken together, it is likely that 
222 the presence of this identical repressor protein is responsible for the lysogenic immunity

223 of CD2315 towards phage infection by $\Phi C D 1801$.

224

225 In a similar manor to the above, $\Phi C D 08011$ possessed a stringent affinity towards the RT 226 from which it was isolated. Indeed, the phage could infect 15/23 RT 002 isolates 227 representing $65.2 \%$ coverage (Fig. 3). The remaining two phages demonstrated 228 remarkably lower host range activity than the abovementioned phages. ФCD2301 was 229 only able to infect 3/19 RT 014 strains representing only $15.8 \%$ host range coverage. In 230 addition to the three RT 014 strains, DCD2301 was shown to infect the RT 106 isolate $231 \mathrm{CDDH} 183$, albeit with a low EOP value. Finally, $\Phi C D 418$ was able to infect only $3 / 14$ of the 232 tested RT 023 strains representing $21.4 \%$ host range coverage.

233

234 Taken together, it appears that the phages isolated herein appear to have essentially strict 235 sensitivity to one particular RT. This differs from most of the previously published phages 236 in which cross-ribotype sensitivity is frequently observed [15]. This phenomenon is 237 unexplained at present but could relate to the sample origin for phage isolation. In our 238 study, we used sewage samples from the UK which are ultimately derived from human 239 faeces. Other studies utilised purely environmental samples for phage isolation, for example soil [15]. 
bioRxiv preprint doi: https://doi org/10.1101/2021.0526.445907: this version posted May 29, 2021. The copyright holder for this preprint (which was not certified by peer review) is the author/funder, who has granted bioRxiv a license to display the preprint in perpetuity. It is made available under aCC-BY 4.0 International license.
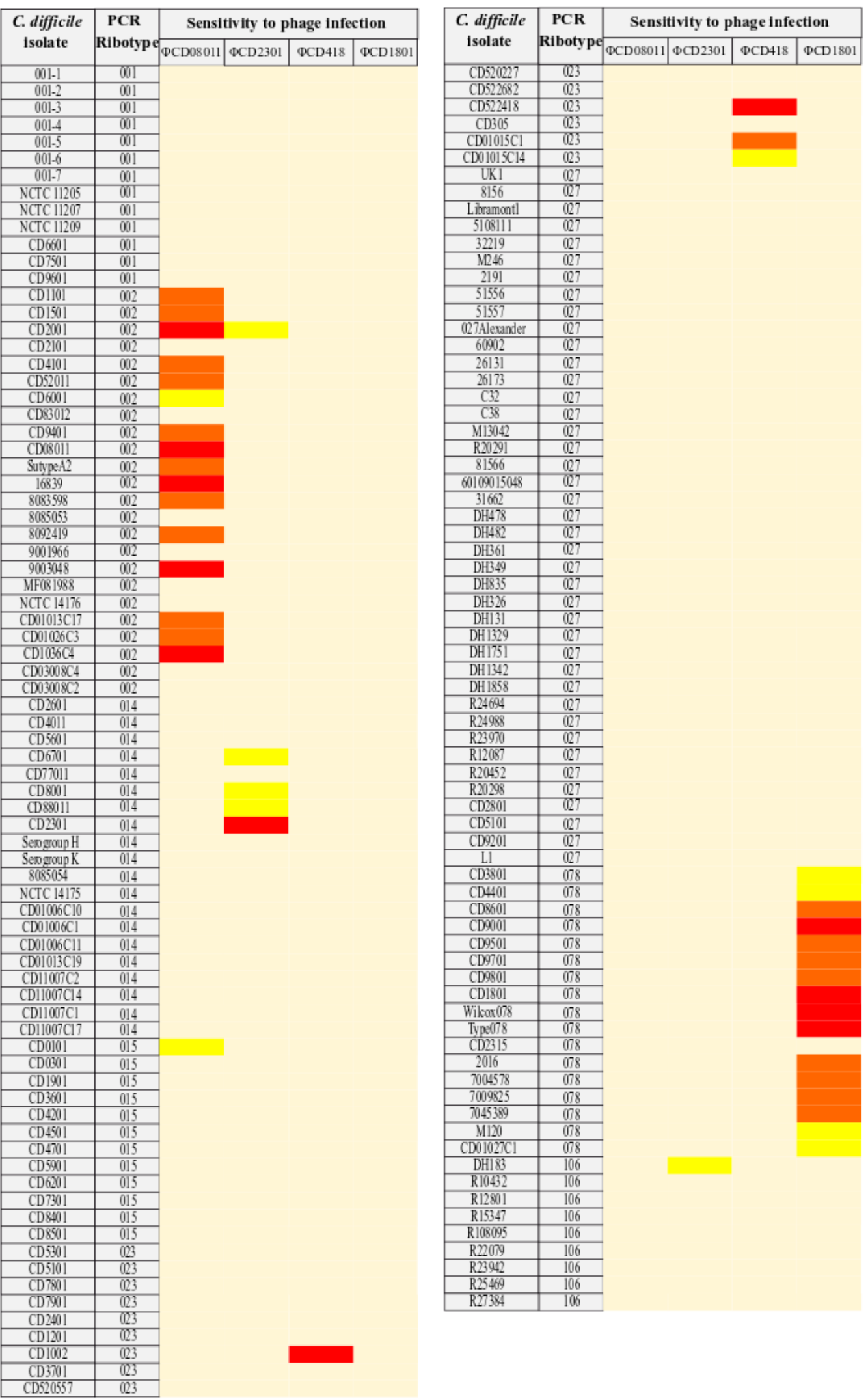

243 Figure 3: Heat map of $\boldsymbol{C}$. difficile sensitivity to bacteriophage infection. Phage host range

244 was determined using standard plaque assays for phages ФCD08011, ФCD2301, ФCD418 and 
245

246

ФCD1801. Efficiency of plating (EOP) values are depicted for each infection study represented by colour. Magenta: resistant strain; yellow: EOP $<0.1$; orange: EOP $0.1-1$; red: EOP $>1$.

\section{Identification of the S-layer as the surface receptor for $\Phi$ CD1801}

The S-layer of $C$. difficile is a para-crystalline protein that coats the entire bacterial cell, comprised of a precursor protein SIpA that is post-translationally cleaved into high molecular weight and low molecular weight SIpA derivatives [19]. The gene encoding SIpA is located within a hypervariable S-layer cassette (SLC) comprising a five-gene cluster containing s/pA, sec2A, cwp2, cwp66 and cwp2790. Thus far, 14 S-layer cassette types (SLCT) have been determined, where the variability is mainly ascribed to sequence differences within the low molecular weight component of $s / p A$ [20]. Research conducted on a novel R-type bacteriocin (Avidocin-CD), uncovered SIpA as the surface receptor for these novel antibacterial agents, since sensitivity could be conferred to a resistant strain in an SLCT-dependent manner [9]. Owing to R-type bacteriocins naturally resembling Myovirus phage tail-proteins [21], the authors provided a clear indication that SIpA is a likely surface receptor candidate for Myovirus phage infection in C. difficile. Although Phothichaisri and colleagues have demonstrated a physical interaction between phage particles and the surface layer of $C$. difficile by means of native-PAGE analysis [10], hitherto, no research has been conducted to verify the relationship between SLCTs and their interaction with $C$. difficile phages.

In order to determine the relationship between various SLCTs and our bacteriophage, we conjugated pJAK002 comprising pRPF185, expressing the RT 078-derived hybrid S-layer cassette (H2/6), as well as the individual H2 (pJAK023) and H6 SLCs (pJAK018) [9], into the RT 012 strain 630. Following successful conjugation, the recipient strain was assessed for its ability to bind $\Phi C D 1801$, by means of a binding assay. These analyses revealed that CD630 was unable to bind $\Phi C D 1801$ (Fig. 4). Thus, no substantial reduction in titer was observed $(\geq 1-\log )$, between the initial phage inoculum and the number of unbound phage particles following plaque assay in strain CD1801. However, in the presence of plasmid- 
borne SLCS H2/6 and 6 encoded on pJAK002 and pJAK018, respectively, ФCD1801 bound

to CD630 as indicated by a substantial decrease in the number of unbound phage particles observed (Fig. 4). The same pattern was observed when we tested the two RT 027 strains CDDH1916 and CD31662 (Fig. S1). Taken together, these data demonstrate that phage binding for $\Phi C D 1801$, is dependent on the SLCT. Therefore, our results corroborate the above-mentioned findings $[9,10]$, thus affirming SIpA as the surface receptor for bacteriophage infection by $C$. difficile Myoviruses.

283

Given the notion that 14 SLCTs exist for $C$. difficile, it can be reasonably assumed that an optimal phage cocktail of up-to 14 phages will be required for broad host-range coverage against CDI. To achieve this milestone, efforts must first be made towards the isolation and characterisation of phages, which are able to individually infect strains harbouring one of the 14 SLCTs. Doing so has the potential to considerably enhance the therapeutic prospect of phage therapy for the treatment of CDI.

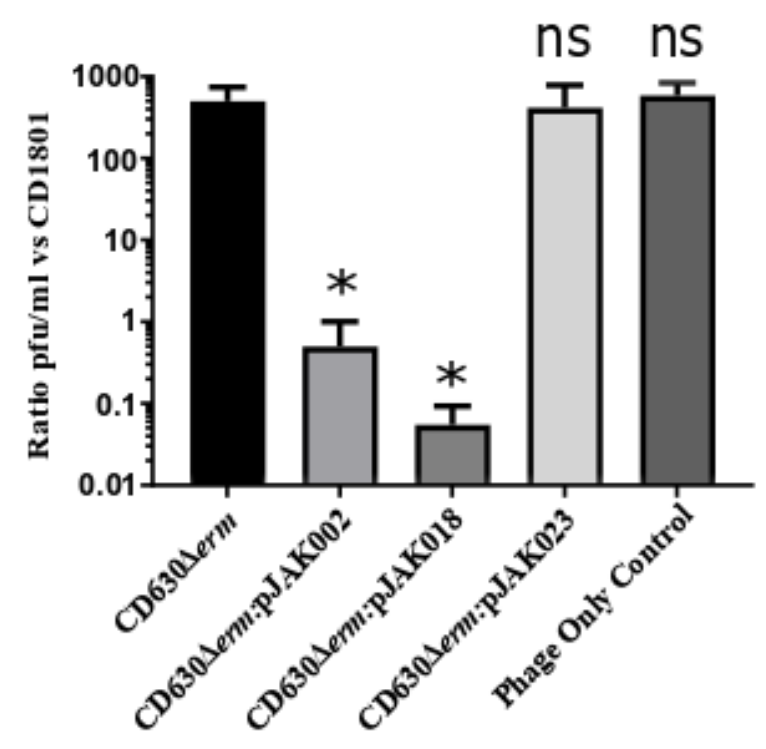

Figure 4: Phage binding is SLCT-dependent in RT 012. The capacity for CD630 to bind to ФCD1801 was assessed by means of a phage binding assay with wild-type CD630 and CD630 harnessing plasmid-borne SLC H2/6 (pJK002), SLC 6 (pJK018) and SLC 2 (pJK023) under the control of a tetracycline inducible promoter. Following co-incubation with wild-type or plasmid-bearing 
propagating strain $C D 18101$ as an indicator. Data represent the mean \pm SD of 3 biological replicates P-* $<0.05$ according to One-Way ANOVA followed by Dunnett's multiple comparison test.

298

\section{Conclusions}

300 Four novel bacteriophages infecting $C$. difficile have been isolated from UK sewage samples: ФCD08011, ФCD418, ФCD1801 and ФCD2301. While ФCD08011, ФCD418 ФCD1801 and ФCD2301 were comparable to other phages reported in the literature, ФCD1801 was shown to possess the broadest reported host-range activity towards RT 078 strains of C. difficile, wherein $15 / 16(93.75 \%)$ of clinical isolates were susceptible to lysogenic infection. To consolidate reports suggesting SIpA as the surface receptor for $C$. difficile phage infection, we showed that $\Phi C D 1801$ was able to bind its own RT but unable to bind to RT 012 or RT 027 strains. Plasmid-borne expression of the RT $078-\mathrm{SLC}(\mathrm{H} 2 / 6)$ in RT 012 and RT 027 strains was able to remedy this phenomenon, thus confirming the notion that SIpA, the major constituent of the S-layer, represents the phage receptor on the surface of $C$. difficile.

\section{Methods}

\section{Routine growth of $\boldsymbol{C}$. difficile strains}

C. difficile isolates were routinely grown on brain heart infusion (BHI) medium

supplemented with $0.5 \%$ yeast extract, $0.1 \%$ L-cysteine and C. difficile selective supplement comprising $250 \mu \mathrm{g} / \mathrm{mL}$ D-cycloserine and $8 \mu \mathrm{g} / \mathrm{ml}$ cefoxitin (Oxoid, USA), referred to as BHIs. Strains were maintained at $37^{\circ} \mathrm{C}$ under anaerobic conditions in a Don

\section{Isolation of C. difficile from stool samples}

Novel C. difficile isolates used within this study were isolated from patient faecal samples 
$1: 1$ with PBS, heat shocked at $80^{\circ} \mathrm{C}$ for $15 \mathrm{~min}$ and centrifuged for $5 \mathrm{~min}$ at $1500 \times \mathrm{g}$. A $50 \mu \mathrm{L}$ aliquot of the supernatant was used to inoculate triplicate Cycloserine Cefoxitin Egg Yolk (CCEY) agar plates (LabM, UK) in an anaerobic cabinet and incubated for $48 \mathrm{~h}$. Plates were prepared by autoclaving $48 \mathrm{~g}$ premixed CCEY in $1 \mathrm{~L} \mathrm{dH} 2 \mathrm{O}$ and adding $40 \mathrm{~mL}$ (4\%) egg yolk emulsion (Lab M, UK) post-autoclave. Prior to use, the plates were kept under anaerobic conditions for a minimum of $4 \mathrm{~h}$. Putative $C$. difficile isolates were transferred into a 96 microtiter plate containing $200 \mu \mathrm{L}$ BHIS broth, one per well and up to 20 per patient sample. Microtiter plates were sealed with breathable sterile film and incubated overnight in anaerobic conditions. A separate 96 well microtiter plate contained $180 \mu \mathrm{L}$ PCR grade $\mathrm{H}_{2} \mathrm{O}$ where a 1:10 dilution was made from the overnight broth cultures. A drop of glycerol was then added to the broth cultures and resealed using fresh breathable sterile film and stored at $-80^{\circ} \mathrm{C}$. The $\mathrm{H}_{2} \mathrm{O}$ culture mix was covered in breathable sterile film and stored at $-20^{\circ} \mathrm{C}$ for subsequent use as a PCR template for ribotyping. A complete list of strains used in this study is provided in Table S1.

\section{Ribotyping}

343 Ribotyping of the clinical isolates was performed exactly as described previously [22],

344 following the extraction of DNA from the abovementioned treated stool samples by heating at $95^{\circ} \mathrm{C}$ for 20 min after initial defrosting. PCR products were visualised using a Qiaexcel using the Qiaexcel DNA High Resolution (Qiagen, Germany). Band profiles were analysed by eye in the first instance before sending each isolate to the $C$. difficile Reference Network (CDRN) at Leeds Royal Infirmary (Leeds, UK) where for official assignment of strain ribotype.

\section{Isolation of phages}

353 Sewage samples were obtained from an anaerobic digester at Stoke Bardolph sewage 354 treatment plant in Nottinghamshire, UK. The sewage sample (50 mL) was enriched overnight, anaerobically, with the dry components of BHIs with the addition of $1 \%$ 

isolates obtained at the Queens Medical Centre, Nottingham, UK. Phages were identified through plaque formation and plaques were subsequently purified three times. Lysogens of the isolated phage within the propagating strain CD1801, were isolated using the spot on the plate method as previously described [23]. Lysogens were then confirmed by induction of prophage using Mitomycin $\mathrm{C}(3 \mu \mathrm{g} / \mathrm{mL})$ in accordance with established methods [24]. Finally, lysogens were screened for their immunity to further phage infection by means of plaque assay.

\section{Enumeration of phages}

Phages were enumerated using the double agar overlay plaque assay, in accordance with a published protocol [25].

\section{Transmission electron microscopy}

Isolated phage lysates $\left(>10^{9} \mathrm{pfu} / \mathrm{mL}\right)$, were precipitated by $1 \mathrm{M}$ ammonium acetate (Sigma Aldrich, USA) as described by Fortier and Moineau (2007), with centrifugation steps at $21,000 \times \mathrm{g}$ for $75 \mathrm{~min}$ [14]. The precipitated phage particles were stained with $10 \mu \mathrm{L}$ of $2 \%$ uranyl acetate (Sigma Aldrich, USA) for 30s on 200 mesh Formavar carbon coated copper grids, before visualising through transmission electron microscopy (TEM) following an established method [14].

\section{Extraction of phage genomic DNA}

380 Phage genomic DNA was extracted from crude phage lysate using a modified phenol/chloroform method [8]. A $2 \mathrm{~mL}$ volume of crude phage lysate ( $10^{9} \mathrm{pfu} / \mathrm{mL}$ ) was mixed with $25 \mu \mathrm{L} \mathrm{MgCl}_{2}$ (1M, Sigma), $0.8 \mu \mathrm{L}$ DNase I (2000 U/ml, Thermo Fisher Scientific) and $20 \mu \mathrm{l}$ RNAse A (10 mg/ml, Thermo Fisher Scientific) and incubated at room temperature for $30 \mathrm{~min}$. Subsequently, $80 \mu \mathrm{L}$ EDTA (0.5 M, Thermo Fisher Scientific), 5 
added to the phage- $\mathrm{MgCl}_{2}$ mixture and incubated at $55^{\circ} \mathrm{C}$ for $1 \mathrm{~h}$. The resulting liquid was aliquoted into 4 phase lock tubes (Quanta Biosciences) and extracted 3 times with an equal volume of phenol:chloroform:isoamylalcohol (25:24:1, Sigma). A final extraction with an equal volume of chloroform (Sigma) was conducted before the DNA was precipitated using 2 volumes $100 \%$ ethanol and 0.1 volumes sodium acetate (Sigma) and incubated on ice for $5 \mathrm{~min}$. All centrifugation steps were performed at $13,000 \mathrm{rpm}$ for $5 \mathrm{~min}$. The precipitated DNA was centrifuged at $13,000 \mathrm{rpm}$ for $10 \mathrm{~min}$ and resulting pellet washed with $1 \mathrm{ml} 70 \%$ ethanol. The centrifugation step was repeated and the pellet air-dried before the DNA was dissolved in $10 \mathrm{mM}$ Tris- $\mathrm{HCl}\left(\mathrm{pH} \mathrm{8.5,} \mathrm{Qiagen)} \mathrm{at} 65^{\circ} \mathrm{C}\right.$ for $20 \mathrm{~min}$. Eluted DNA was pooled, quantified using NanoDrop Lite spectrophotometer (Thermo Scientific) and stored at $4^{\circ} \mathrm{C}$ before sequencing.

\section{Sequencing and annotation of genomes}

Full genome sequencing of $C$. difficile strain CD2315 and purified phages was conducted by DeepSeq (University of Nottingham) using an Illumina MiSeq platform. For CD2315, paired reads were aligned to the archetypal genome sequence of strain M120. For the phage genomes, raw sequencing reads were assembled into a single contig using de novo assembly function within CLC Genomics Workbench 9.5.3 (Qiagen). Artemis software [26] was used to identify putative open reading frames (ORFs). Manual genome annotation was completed using NCBI BLASTp, UniProt and pfam databases to assign putative protein functions. ORFs were manually trimmed to the correct start codon based on the presence of ribosome binding sites and promoter sequences.

\section{Determination of phage host range testing}

410 Standard plaque assay was used to determine the host range of the isolated phage using 411 a $\sim 10^{9} \mathrm{pfu} / \mathrm{mL}$ stock according to established methods [25]. Efficiency of plating was 412 determined for each indicator strain by comparison of the phage titer using the 413 propagating strain against the phage titer using the indicator strain (EOP = phage titer of 414 propagating strain $\div$ phage titer of indicator strain). Tested strains are listed in Table S1. 415 PHAge Search Tool Enhanced Release (PHASTER) was used to identify prophage regions 
416 within the genome of resistant isolates [18]. Putative repressor proteins were aligned

417 using The European Molecular Biology Open Software Suite (EMBOSS) pairwise alignment

418 tool [16].

419

420

421

422

423

424

425

426

427

428

429

430

431

432

433

434

435

436

437

438

439

440

441

442

443

444

445

\section{S-layer receptor testing}

pRPF185 plasmids expressing the hybrid RT 078 S-layer cassette (H2/6) (pJAK002) and the individual SLCS 2 (pJAK023) and 6 (pJAK018), under the control of an anhydrotetracycline-inducible promoter, were obtained from Robert Fagan (University of Sheffield, UK) [27]. pRPF185 was conjugated into C. difficile 630 exactly as described previously using E. coli CA434 as a conjugal donor strain [28]. A $1 \%$ inoculum of an overnight culture of the transformed strain was transferred to $20 \mathrm{~mL}$ pre-reduced BHIs broth and incubated for $4 \mathrm{~h}$ before being induced with anhydrotetracycline (Sigma Aldrich, USA) to a final concentration of $500 \mathrm{ng} / \mathrm{mL}$ in a $20 \mathrm{~mL}$ culture for $1 \mathrm{~h}$ under anaerobic conditions. To detect phage binding in the presence and absence of the RT 078 S-layer cassette, a binding assay was conducted. Therein, $20 \mathrm{~mL}$ of induced cultures were harvested by centrifugation and the resulting cell pellet re-suspended in $10 \mu \mathrm{L}$ of phage $\left(10^{4} \mathrm{pfu} / \mathrm{ml}\right)$. This was incubated for $15 \mathrm{~min}$ under anaerobic conditions to allow the phage to bind before being re-suspended in $1 \mathrm{~mL}$ BHIs broth. A final centrifugation step was completed to remove the bacterial cells. The number of phage particles in the supernatant that had not bound to cells was enumerated using plaque assay as mentioned above, using CD1801 as an indicator. A substantial reduction in phage titer from the infection phage titer is indicative of phage binding. C. difficile 630 and 1801 were used as negative and positive binding controls, respectively.

\section{Acknowledgements}

We thank Rob Fagan (University of Sheffield) for his kind donation of SLC-expressing derivatives of pRPF185 and his advice regarding the S-layer. We would also like to thank Erasmus students Arlen-Celina Lücke (University of Hanover) and Renske van Esveld 
446 (Leiden University) for their contribution to laboratory work. This work was supported by

447 a Medical Research Council Industrial CASE (MRC; grant No. MR/K017829/1) with Phico

448 Therapeutics Ltd and by the NIHR Nottingham BRC (Reference no. BRC-1215-20003). The

449 views expressed are those of the authors and not necessarily those of the funders.

450

451

452

453

454

455

456

457

458

459

460

461

462

463

464

465

466

467

468

469

470

471

472

473

474

475

476

N.P.M conceived the study and all experimental work on phage isolation and characterisations was undertaken by M.J.W. M.M.L. isolated and characterised all Nottingham-derived C. difficile 078 strains, M.J.W. and T.W.B. undertook all genome analysis and annotation and drafted the manuscript. All authors reviewed, edited, and approved the final version of the manuscript.

We declare no conflicts of interest.

\section{References}

1. Lawson PA, Citron DM, Tyrrell KL, Finegold SM. 2016. Reclassification of Clostridium difficile as Clostridioides difficile (Hall and O'Toole 1935) Prevot 1938. Anaerobe 40:95-9.

2. Lessa FC, Mu Y, Bamberg WM, Beldavs ZG, G.K. Dumyati, J.R. Dunn, M.M. Farley, S.M. Holzbauer, J.I. Meek, and E.C. Phipps. 2015. Burden of Clostridium difficile infection in the United States. N Engl J Med 372(24):2369-70.

3. Theriot CM, Young VB. 2014. Microbial and metabolic interactions between the gastrointestinal tract and Clostridium difficile infection. Gut Microbes 5(1):86-95.

4. Higa JT, Kelly CP. 2014. New drugs and strategies for management of Clostridium difficile colitis. J Intensive Care Med. 29(4):190-9. 
$477 \quad$ 5. Chang JY, Antonopoulos DA, Kalra A, Tonelli A, Khalife WT, Schmidt TM, Young VB. 2008. Decreased diversity of the fecal Microbiome in recurrent Clostridium difficileassociated diarrhea. J Infect Dis 197(3):435-8.

6. Ross A, Ward S, Hyman P. 2016. More Is Better: Selecting for Broad Host Range Bacteriophages. Front Microbiol 7:1352-1352.

7. Krutova M, Zouharova M, Matejkova J, Tkadlec J, Krejci J, Faldyna M, Nyc O, Bernardy J. 2018. The emergence of Clostridium difficile PCR ribotype 078 in piglets in the Czech Republic clusters with Clostridium difficile PCR ribotype 078 isolates from Germany, Japan and Taiwan. Int J Med Microbio/308(7):770-775.

8. Nale JY, Spencer J, Hargreaves KR, Buckley AM, Trzepiński P, Douce GR, Clokie MRJ. 2016. Bacteriophage Combinations Significantly Reduce Clostridium difficile

9. Kirk JA, Gebhart D, Buckley AM, Lok S, Scholl D, Douce GR, Govoni GR Fagan RP+. 2017. New class of precision antimicrobials redefines role of Clostridium difficile Slayer in virulence and viability. Sci Trans Med 9(406):eaah6813.

10. Phothichaisri W, Ounjai $P$, Phetruen $T$, Janvilisri T, Khunrae $P$, Singhakaew S, Bacteriophages Infecting Clinical Isolates of Clostridium difficile. Front Microbiol 9:1701-1701.

11. Wu Y-C, Lee JJ, Tsai BY, Liu YF, Chen CM, Tien N, Tsai PJ, Chen TH. 2016. Potentially hypervirulent Clostridium difficile PCR ribotype 078 lineage isolates in pigs and possible implications for humans in Taiwan. Int J Med Microbio/ 306(2):115-122. AA, Dekker FW, Kuijper EJ. 2008. Emergence of Clostridium difficile infection due to 
503 13. O'Connor JR, Johnson S, Gerding DN. 2009. Clostridium difficile Infection Caused by the Epidemic BI/NAP1/027 Strain. Gastroenterol 136(6):1913-1924.

505

14. Fortier L-C, Moineau S. 2007. Morphological and Genetic Diversity of Temperate 506 Phages in Clostridium difficile. Appl Environ Microbiol 73(22):7358-7366.

15. Rashid SJ, Barylski J, Hargreaves KR, Millard AA, Vinner GK, Clokie MRJ. 2016. Two Novel Myoviruses from the North of Iraq Reveal Insights into Clostridium difficile Phage Diversity and Biology. Viruses 8(11):310.

16. Rice P, Longden I, Bleasby A. 2000. EMBOSS: the European Molecular Biology Open Software Suite. Trends Genet 16(6):276-7.

17. Mayer MJ, Narbad A, Gasson MJ. 2008. Molecular characterization of a Clostridium difficile bacteriophage and its cloned biologically active endolysin. J Bacteriol 190(20):6734-40.

18. Arndt D, Grant JR, Marcu A, Sajed T, Pon A, Liang Y, Wishart DS. 2016. PHASTER: 21.

19. Kirk JA, Banerji O, Fagan RP. 2017. Characteristics of the Clostridium difficile cell envelope and its importance in therapeutics. Microb Biotechnol 10(1):76-90.

20. Fagan RP, Albesa-Jove D, Qazi O, Svergun DI, Brown KA, Fairweather NF. 2009. Structural insights into the molecular organization of the S-layer from Clostridium difficile. Mol Microbiol 71(5):1308-22.

21. Ge P, Scholl D, Leiman PG, Yu X, Miller JF, Zhou ZH. 2015. Atomic structures of a bactericidal contractile nanotube in its pre- and postcontraction states. Nat Struct Mol Biol 22(5):377-82 
526

527

528

529

530

531

532

533

534

535

536

537

538

539

540

541

542

543

22. O'Neill G, Ogunsola F, Brazier J, Duerden B. 1996. Modification of a PCR Ribotyping Method for Application as a Routine Typing Scheme for Clostridium difficile. Anaerobe. 12(4):205-9.

23. Govind R, Vediyappan G, Rolfe RD, Dupuy B, Fralick JA. 2009. Bacteriophagemediated toxin gene regulation in Clostridium difficile. $J$ Virol 83(23):12037-12045.

24. Sell TL, Schaberg DR, Fekety FR. 1983. Bacteriophage and bacteriocin typing scheme for Clostridium difficile. J Clin Microbiol 17(6):1148-1152.

25. Clokie MRJ, Kropinski A. (2009). Bacteriophages. Methods and Protocols: Isolation, Characterization, and Interactions, Vol. 1, eds M. R. J. Clokie and A. M. Kropinski (Totowa, NJ: Humana Press).

26. Rutherford K, Parkhill J, Crook J, Horsnell T, Rice P, Rajandream MA, Barrell B. 2000. Artemis: sequence visualization and annotation. Bioinformatics 16(10):944-5.

27. Fagan RP, Fairweather NF. 2011. Clostridium difficile has two parallel and essential Sec secretion systems. J Biol Chem 286(31):27483-93.

28. Cartman ST, Minton NP. 2010. A mariner-Based Transposon System for In Vivo Random Mutagenesis of Clostridium difficile. Appl Environ Microbio/ 76(4):1103-1109. 
bioRxiv preprint doi: https://doi.org/10.1101/2021.05.26.445907; this version posted May 29, 2021. The copyright holder for this preprint (which was not certified by peer review) is the author/funder, who has granted bioRxiv a license to display the preprint in perpetuity. It is

a) made available under aCC-BY 4.0 International license.

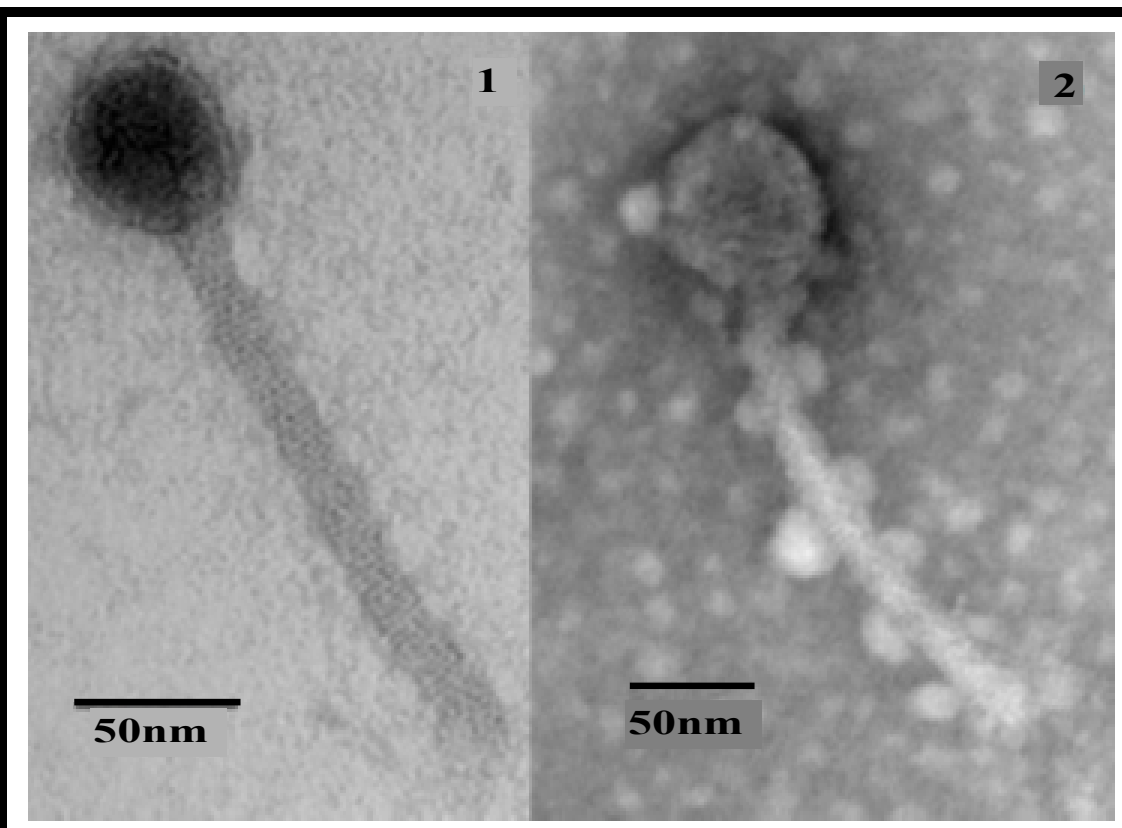

Tail length: $204.0 \pm 5.1 \mathrm{~nm}$

Tail diameter: $16.9 \pm 1.6 \mathrm{~nm}$

Capsid diameter: $58.1 \pm 5.4 \mathrm{~nm}$

c)

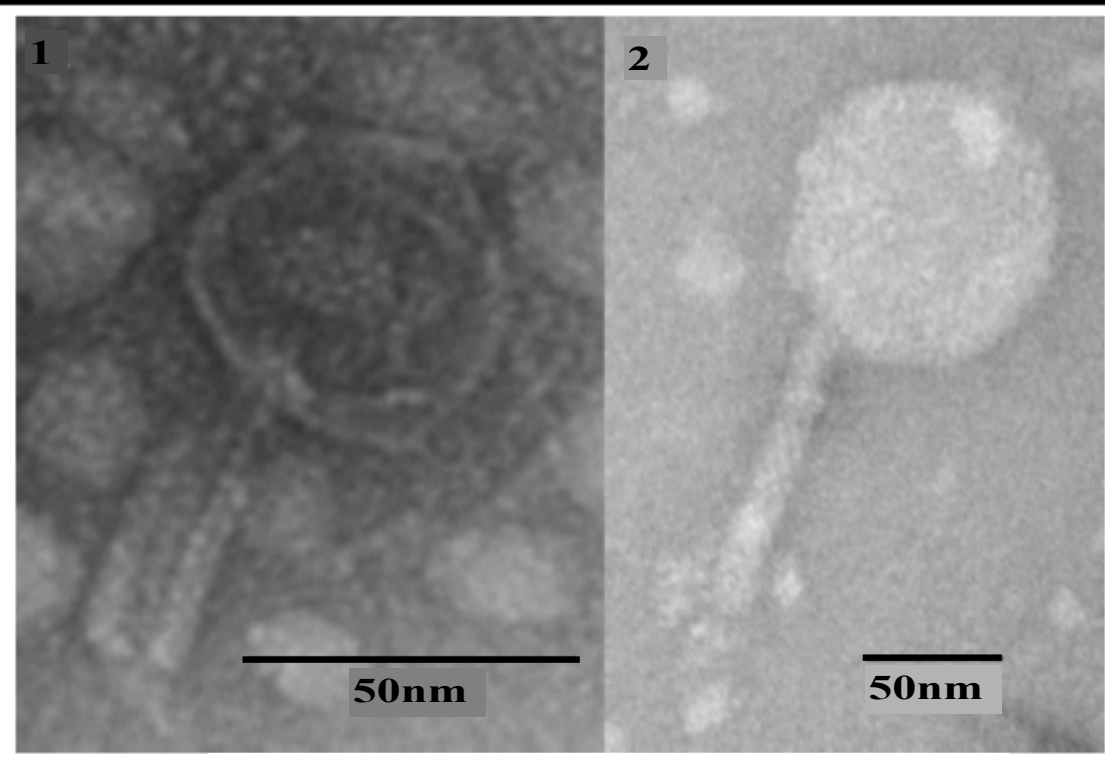

Tail length: cannot be determined

Tail diameter: cannot be determined

Capsid diameter: cannot be determined b)

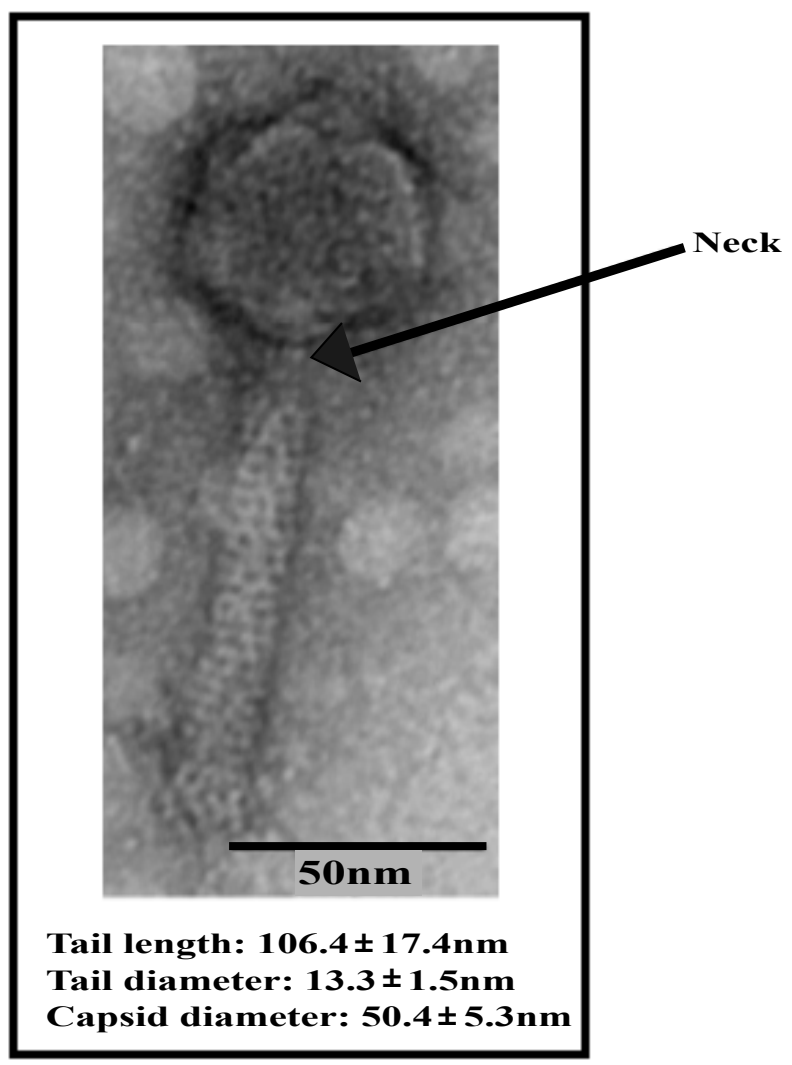

d)

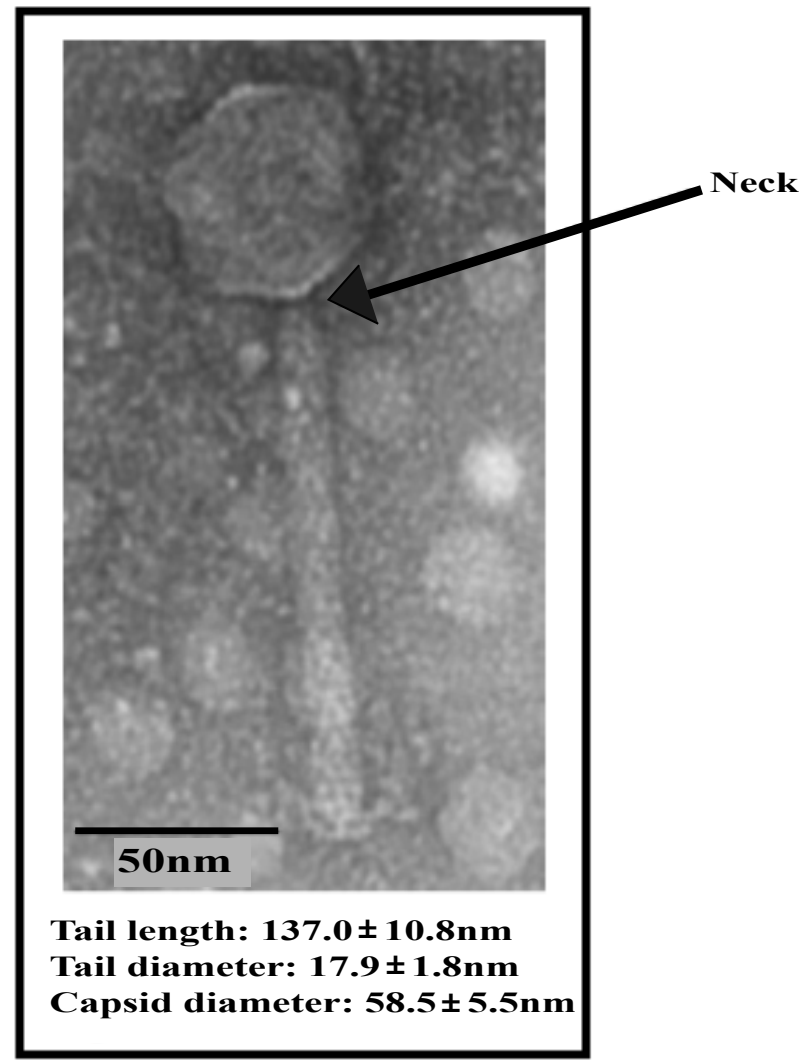


Transposase

a)

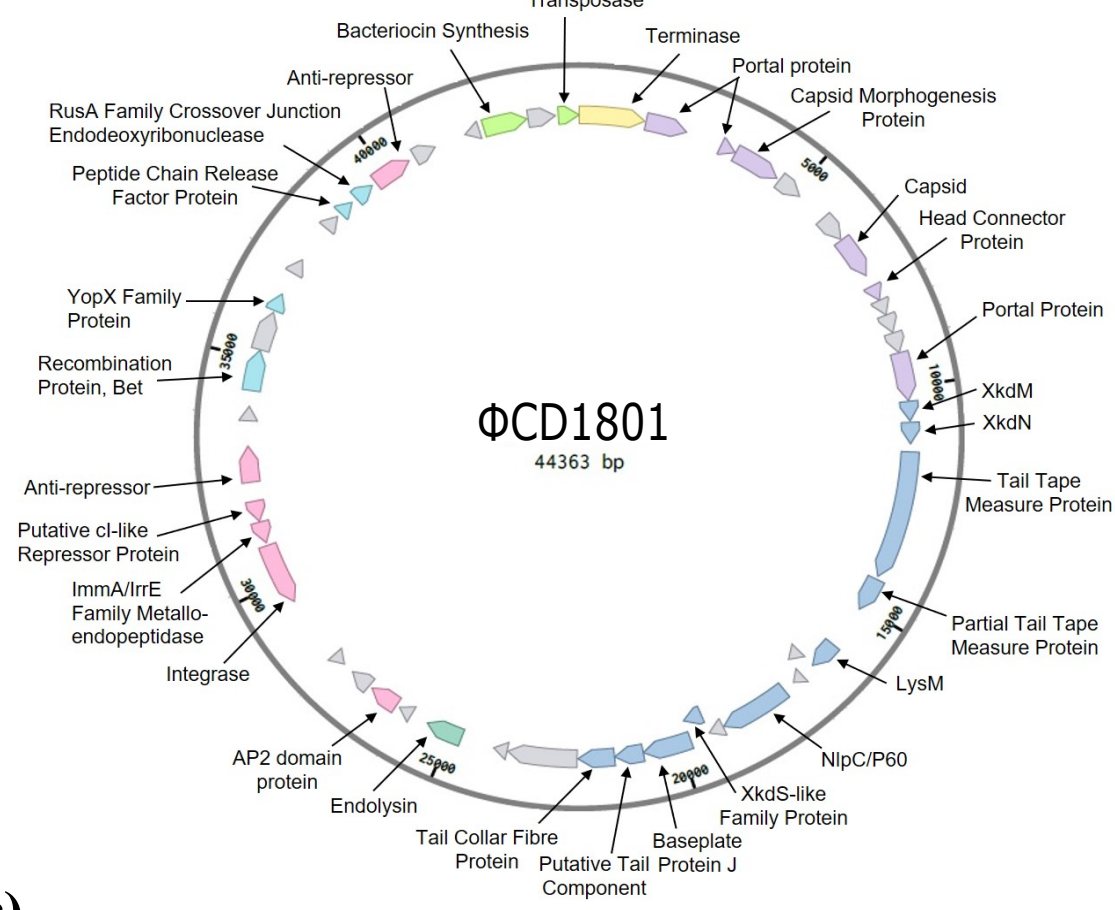

c)

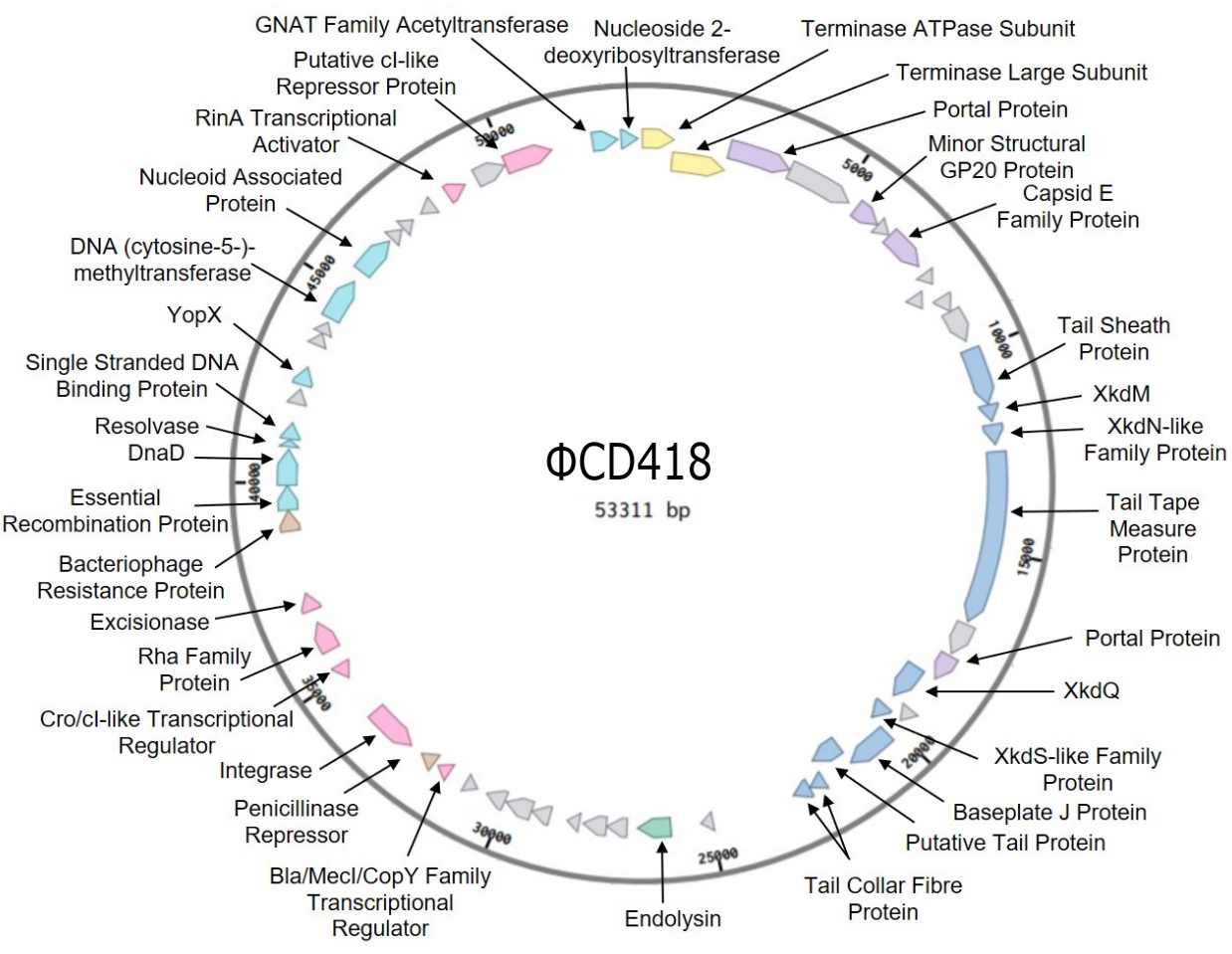

\section{b)}

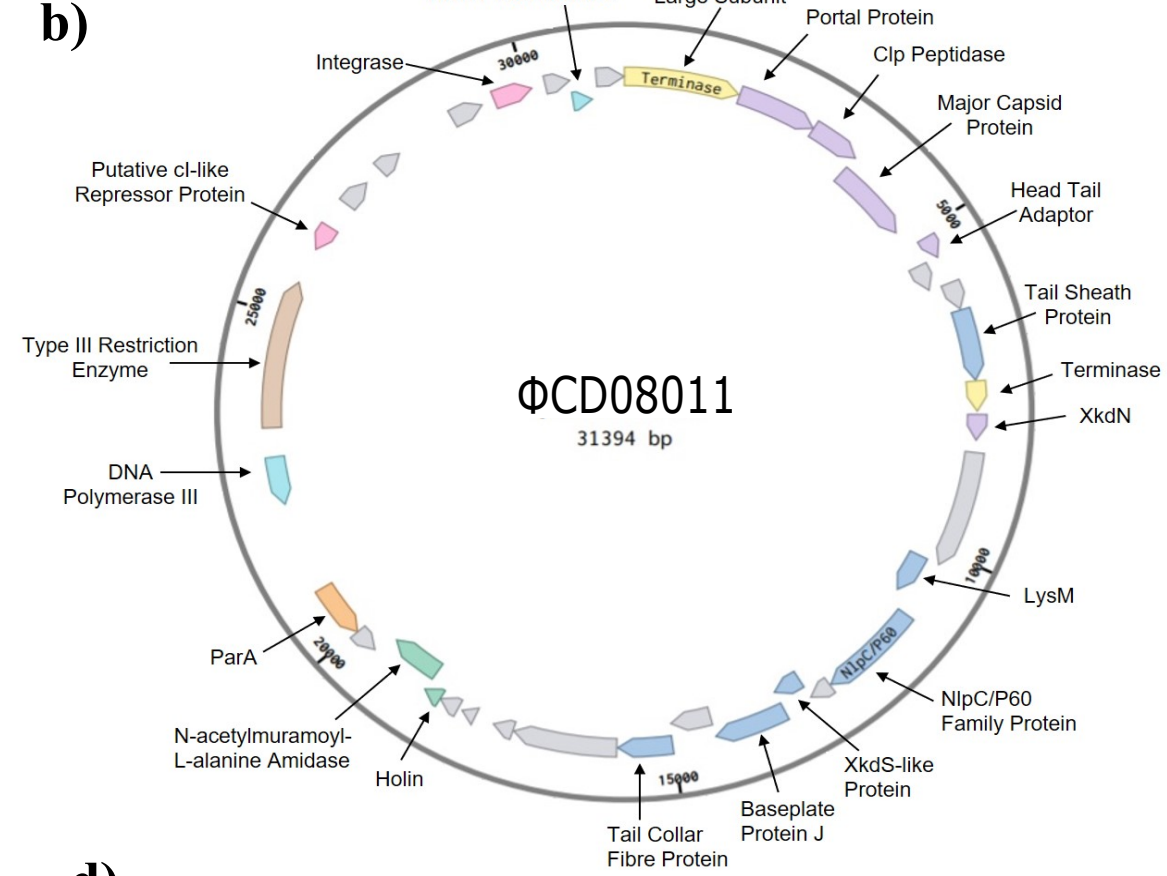

d)




bioRxiv preprint doi: https://doi.org/10.1101/2021.05.26.445907; this version posted May 29, 2021. The copyright holder for this preprint

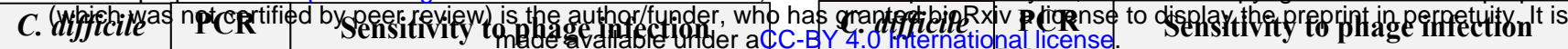

\begin{tabular}{|c|c|c|c|c|c|}
\hline \multirow{2}{*}{ isolate } & \multirow{2}{*}{ Ribotype } & \multicolumn{4}{|l|}{. } \\
\hline & & $\Phi C D 08011$ & ФCD2301 & ФCD418 & ФCD1801 \\
\hline
\end{tabular}

\begin{tabular}{|c|c|c|c|c|c|}
\hline isolate & Ribotype & ФCD08011 & ФCD2301 & ФCD418 & ФCD1801 \\
\hline CD520227 & 023 & & & & \\
\hline CD522682 & 023 & & & & \\
\hline CD522418 & 023 & & & & \\
\hline CD305 & 023 & & & & \\
\hline $\mathrm{CD} 01015 \mathrm{Cl}$ & 023 & & & & \\
\hline CD01015C14 & 023 & & & & \\
\hline UK1 & 027 & & & & \\
\hline
\end{tabular}

\begin{tabular}{|c|c|}
\hline $001-7$ & 001 \\
\hline NCTC 11205 & 001 \\
\hline NCTC 11207 & 001 \\
\hline NCTC 11209 & 001 \\
\hline CD6601 & 001 \\
\hline CD7501 & 001 \\
\hline CD9601 & 001 \\
\hline CD1101 & 002 \\
\hline CD1501 & 002 \\
\hline CD2001 & 002 \\
\hline CD2101 & 002 \\
\hline CD4101 & 002 \\
\hline CD52011 & 002 \\
\hline CD6001 & 002 \\
\hline CD83012 & 002 \\
\hline CD9401 & 002 \\
\hline CD08011 & 002 \\
\hline SutypeA2 & 002 \\
\hline 16839 & 002 \\
\hline 8083598 & 002 \\
\hline 8085053 & 002 \\
\hline 8092419 & 002 \\
\hline 9001966 & 002 \\
\hline 9003048 & 002 \\
\hline MF081988 & 002 \\
\hline NCTC 14176 & 002 \\
\hline CD01013C17 & 002 \\
\hline CD01026C3 & 002 \\
\hline CD1036C4 & 002 \\
\hline CD03008C4 & 002 \\
\hline CD03008C2 & 002 \\
\hline CD2601 & 014 \\
\hline CD4011 & 014 \\
\hline CD5601 & 014 \\
\hline CD6701 & 014 \\
\hline CD77011 & 014 \\
\hline CD8001 & 014 \\
\hline CD88011 & 014 \\
\hline CD2301 & 014 \\
\hline Serogroun & 014 \\
\hline
\end{tabular}

\begin{tabular}{|c|c|}
\hline 8156 & 027 \\
\hline Libramont1 & 027 \\
\hline 5108111 & 027 \\
\hline 32219 & 027 \\
\hline
\end{tabular}

\begin{tabular}{|c|c|}
\hline Serogroup K & 014 \\
\hline 8085054 & 014 \\
\hline NCTC 14175 & 014 \\
\hline CD01006C10 & 014 \\
\hline CD01006C1 & 014 \\
\hline CD01006C11 & 014 \\
\hline CD01013C19 & 014 \\
\hline CD11007C2 & 014 \\
\hline CD11007C14 & 014 \\
\hline CD11007C1 & 014 \\
\hline CD11007C17 & 014 \\
\hline CD0101 & 015 \\
\hline
\end{tabular}

\begin{tabular}{|c|c}
\hline CD0101 & 015 \\
\hline CD0301 & 015 \\
\hline CD1901 & 015 \\
\hline CD3601 & 015 \\
\hline CD4201 & 015 \\
\hline CD4501 & 015 \\
\hline CD4701 & 015 \\
\hline CD5901 & 015 \\
\hline CD6201 & 015 \\
\hline CD7301 & 015 \\
\hline CD8401 & 015 \\
\hline CD8501 & 015 \\
\hline CD5301 & 023 \\
\hline CD5101 & 023 \\
\hline CD7801 & 023 \\
\hline CD7901 & 023 \\
\hline CD2401 & 023 \\
\hline CD1201 & 023 \\
\hline CD1002 & 023 \\
\hline CD3701 & 023 \\
\hline CD520557 & 023 \\
\hline
\end{tabular}


bioRxiv preprint doi: https://doi.org/10.1101/2021.05.26.445907; this version posted May 29, 2021. The copyright holder for this preprint (which was not certified by peerfegew) i\$ 19 author/funder, who has granted bioRxiv a license to display the preprint in perpetuity. It is

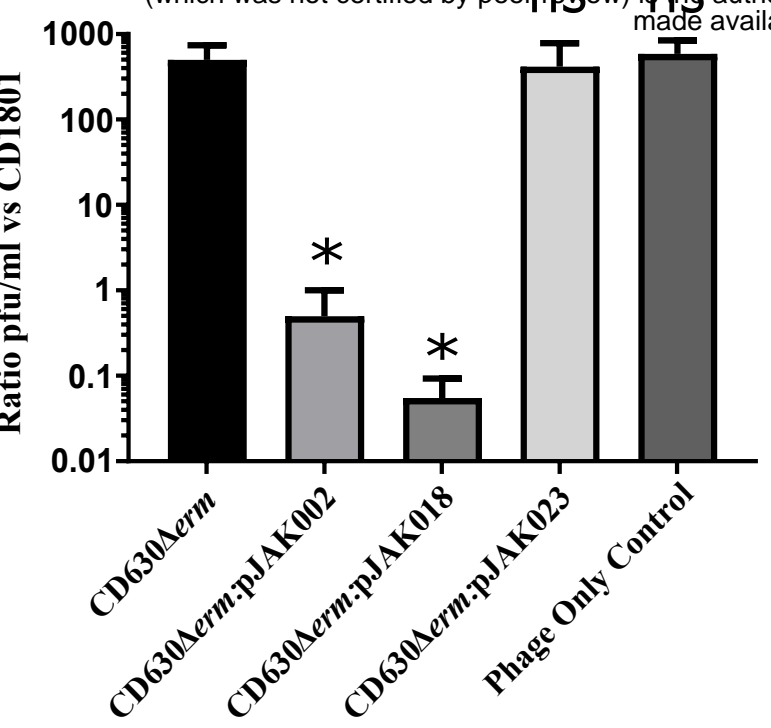




\section{Supplementary information}

\section{A novel bacteriophage with broad host-range against Clostridioides difficile ribotype 078 elucidates the phage receptor}

M.J Whittle ${ }^{1,2}$, T.W Bilverstone ${ }^{1,2}$, R.J van Esveld ${ }^{3}$, A-C. Lücke $^{4}$, M.M Lister ${ }^{1,2}$, S.A Kuehne ${ }^{1,2}$ and N.P Minton ${ }^{1,2 *}$

${ }^{1}$ Clostridia Research Group, BBSRC/EPSRC Synthetic Biology Research Centre (SBRC), School of Life Sciences, Biodiscovery Institute, The University of Nottingham, Nottingham, NG7 2RD, UK.

${ }^{2}$ NIHR Nottingham Biomedical Research Centre, Nottingham University Hospitals NHS Trust and the University of Nottingham, Nottingham, NG7 2RD, UK.

${ }^{3}$ Faculty of Medicine, Leiden University Medical Centre, the Netherlands.

${ }^{4}$ Hannover Medical School, Carl-Neuberg-Straße 1, 30625 Hannover, Germany

Corresponding author: nigel.minton@nottingham.ac.uk

Keywords: Bacteriophage, phage therapy, Clostridioides difficile (Clostridium difficile), Slayer, SIpA. 
Table S1: $C$. difficile isolates used in this study.

\begin{tabular}{|c|c|c|c|}
\hline \multirow{2}{*}{$\begin{array}{l}\text { C. difficile } \\
\text { isolate }\end{array}$} & \\
\hline & ribotype & Origin & Source/Reference \\
\hline 001-1 & RT001 & Netherlands & Ed Kujiper \\
\hline $001-2$ & RT001 & Netherlands & Ed Kujiper \\
\hline $001-3$ & RT001 & Netherlands & Ed Kujiper \\
\hline $001-4$ & RT001 & Netherlands & Ed Kujiper \\
\hline $001-5$ & RT001 & Netherlands & Ed Kujiper \\
\hline $001-6$ & RT001 & Netherlands & Ed Kujiper \\
\hline $001-7$ & RT001 & Netherlands & Ed Kujiper \\
\hline NCTC 11205 & RT001 & Sheffield, UK & NCTC \\
\hline NCTC 11207 & RT001 & Sheffield, UK & NCTC \\
\hline NCTC 11209 & RT001 & Sheffield, UK & NCTC \\
\hline CD66011 & RT001 & Nottinghamshire, UK & SBRC Nottingham \\
\hline CD7501 & RT001 & Nottinghamshire, UK & SBRC Nottingham \\
\hline CD9601 & RT001 & Nottinghamshire, UK & SBRC Nottingham \\
\hline CD1101 & RT002 & Nottinghamshire, UK & SBRC Nottingham \\
\hline CD1501 & RT002 & Nottinghamshire, UK & SBRC Nottingham \\
\hline CD2001 & RT002 & Nottinghamshire, UK & SBRC Nottingham \\
\hline CD2101 & RT002 & Nottinghamshire, UK & SBRC Nottingham \\
\hline CD4101 & RT002 & Nottinghamshire, UK & SBRC Nottingham \\
\hline CD52011 & RT002 & Nottinghamshire, UK & SBRC Nottingham \\
\hline CD6001 & RT002 & Nottinghamshire, UK & SBRC Nottingham \\
\hline CD83012 & RT002 & Nottinghamshire, UK & SBRC Nottingham \\
\hline CD9401 & RT002 & Nottinghamshire, UK & SBRC Nottingham \\
\hline CD08011 & RT002 & Nottinghamshire, UK & SBRC Nottingham \\
\hline SubtypeA2 & RT002 & Netherlands & Ed Kujiper \\
\hline
\end{tabular}




$\begin{array}{llll}16839 & \text { RT002 } & \text { Hungary } & \text { Ed Kujiper } \\ 8083598 & \text { RT002 } & \text { Netherlands } & \text { Ed Kujiper } \\ 8085053 & \text { RT002 } & \text { Netherlands } & \text { Ed Kujiper } \\ 8092419 & \text { RT002 } & \text { Netherlands } & \text { Ed Kujiper } \\ 9001966 & \text { RT002 } & \text { Netherlands } & \text { Ed Kujiper } \\ 9003048 & \text { RT002 } & \text { Netherlands } & \text { Ed Kujiper } \\ \text { MF081988 } & \text { RT002 } & \text { Ireland } & \text { Ed Kujiper }\end{array}$

TL178 (NCTC

$\begin{array}{llll}\text { 14176) } & \text { RT002 } & \text { Northern Ireland } & \text { NCTC } \\ \text { CD01013C17 } & \text { RT002 } & \text { Nottinghamshire, UK } & \text { SBRC Nottingham } \\ \text { CD01026C3 } & \text { RT002 } & \text { Nottinghamshire, UK } & \text { SBRC Nottingham } \\ \text { CD1036C4 } & \text { RT002 } & \text { Nottinghamshire, UK } & \text { SBRC Nottingham } \\ \text { CD03008C4 } & \text { RT002 } & \text { Nottinghamshire, UK } & \text { SBRC Nottingham } \\ \text { CD03008C2 } & \text { RT002 } & \text { Nottinghamshire, UK } & \text { SBRC Nottingham } \\ \text { CD2601 } & \text { RT014 } & \text { Nottinghamshire, UK } & \text { SBRC Nottingham } \\ \text { CD4011 } & \text { RT014 } & \text { Nottinghamshire, UK } & \text { SBRC Nottingham } \\ \text { CD5601 } & \text { RT014 } & \text { Nottinghamshire, UK } & \text { SBRC Nottingham } \\ \text { CD6701 } & \text { RT014 } & \text { Nottinghamshire, UK } & \text { SBRC Nottingham } \\ \text { CD77011 } & \text { RT014 } & \text { Nottinghamshire, UK } & \text { SBRC Nottingham } \\ \text { CD8001 } & \text { RT014 } & \text { Nottinghamshire, UK } & \text { SBRC Nottingham } \\ \text { CD88011 } & \text { RT014 } & \text { Nottinghamshire, UK } & \text { SBRC Nottingham } \\ \text { CD2301 } & \text { RT014 } & \text { Nottinghamshire, UK } & \text { SBRC Nottingham } \\ \text { serogroup H } & \text { RT014 } & \text { Netherlands } & \text { Ed Kujiper } \\ \text { serogroup K } & \text { RT014 } & \text { Netherlands } & \text { Ed Kujiper } \\ \text { 8085054 } & \text { RT014 } & \text { Netherlands } & \text { Ed Kujiper }\end{array}$

TL176 (NCTC

$\begin{array}{llll}\text { 14175) } & \text { RT014 } & \text { Cambridge } & \text { NCTC } \\ \text { CD01006C10 } & \text { RT014 } & \text { Nottinghamshire, UK } & \text { SBRC Nottingham }\end{array}$




\begin{tabular}{|c|c|c|c|}
\hline CD01006C1 & RT014 & Nottinghamshire, UK & SBRC Nottingham \\
\hline CD01006C11 & RT014 & Nottinghamshire, UK & SBRC Nottingham \\
\hline CD01013C19 & RT014 & Nottinghamshire, UK & SBRC Nottingham \\
\hline CD11007C2 & RT014 & Nottinghamshire, UK & SBRC Nottingham \\
\hline CD11007C14 & RT014 & Nottinghamshire, UK & SBRC Nottingham \\
\hline CD11007C1 & RT014 & Nottinghamshire, UK & SBRC Nottingham \\
\hline CD11007C17 & RT014 & Nottinghamshire, UK & SBRC Nottingham \\
\hline CD0101 & RT015 & Nottinghamshire, UK & SBRC Nottingham \\
\hline CD0301 & RT015 & Nottinghamshire, UK & SBRC Nottingham \\
\hline CD1901 & RT015 & Nottinghamshire, UK & SBRC Nottingham \\
\hline CD3601 & RT015 & Nottinghamshire, UK & SBRC Nottingham \\
\hline CD4201 & RT015 & Nottinghamshire, UK & SBRC Nottingham \\
\hline CD4501 & RT015 & Nottinghamshire, UK & SBRC Nottingham \\
\hline CD5701 & RT015 & Nottinghamshire, UK & SBRC Nottingham \\
\hline CD5901 & RT015 & Nottinghamshire, UK & SBRC Nottingham \\
\hline CD6201 & RT015 & Nottinghamshire, UK & SBRC Nottingh \\
\hline CD7301 & RT015 & Nottinghamshire, UK & SBRC Nottingham \\
\hline CD8401 & RT015 & Nottinghamshire, UK & SBRC Nottingham \\
\hline CD8501 & RT015 & Nottinghamshire, UK & SBRC Nottingh \\
\hline CD5301 & RT023 & Nottinghamshire, UK & SBRC Nottingh \\
\hline CD5101 & RT023 & Nottinghamshire, UK & SBRC Nottingl \\
\hline CD7801 & RT023 & Nottinghamshire, UK & SBRC Nottingh \\
\hline CD7901 & RT023 & Nottinghamshire, UK & SBRC Notting \\
\hline CD2401 & RT023 & Nottinghamshire, UK & SBRC Notting \\
\hline CD1202 & RT023 & Nottinghamshire, UK & SBRC Nottir \\
\hline CD1002 & RT023 & Nottinghamshire, UK & SBRC Notting \\
\hline CD3701 & RT023 & Nottinghamshire, UK & SBRC Nottingh \\
\hline CD520557 & RT023 & Nottinghamshire, UK & SBRC Nottingh \\
\hline
\end{tabular}




\begin{tabular}{|c|c|c|c|}
\hline CD520227 & RT023 & Nottinghamshire, UK & SBRC Nottingham \\
\hline CD522682 & RT023 & Nottinghamshire, UK & SBRC Nottingham \\
\hline CD522418 & RT023 & Nottinghamshire, UK & SBRC Nottingham \\
\hline CD305 & RT023 & London, UK & Brendan Wren \\
\hline CD01015C1 & RT023 & Nottinghamshire, UK & SBRC Nottingham \\
\hline CD01015C14 & RT023 & Nottinghamshire, UK & SBRC Nottingham \\
\hline UK1 & RT027 & Stoke Mandeville, UK & Jon Brazier \\
\hline L1 & RT027 & Unknown & Ed Kujiper \\
\hline 8156 & RT027 & France & Ed Kujiper \\
\hline Libramont1 & RT027 & France & Ed Kujiper \\
\hline 5108111 & RT027 & Netherlands & Ed Kujiper \\
\hline 32219 & RT027 & Luxembourg & Ed Kujiper \\
\hline M246 & RT027 & Ireland & Ed Kujiper \\
\hline 2191 & RT027 & Ireland & Ed Kujiper \\
\hline 51556 & RT027 & Germany & Ed Kujiper \\
\hline 51557 & RT027 & Germany & Ed Kujiper \\
\hline 027Alexander & RT027 & Austria & Ed Kujiper \\
\hline 60902 & RT027 & Switzerland & Ed Kujiper \\
\hline 26131 & RT027 & Finland & Ed Kujiper \\
\hline 26173 & RT027 & Finland & Ed Kujiper \\
\hline C32 & RT027 & USA & Ed Kujiper \\
\hline C38 & RT027 & USA & Ed Kujiper \\
\hline M13042 & RT027 & Canada & Ed Kujiper \\
\hline R20291 & RT027 & Stoke Mandeville, UK & Jon Brazier \\
\hline 81566 & RT027 & France & Ed Kujiper \\
\hline 60109015048 & RT027 & Netherlands & Ed Kujiper \\
\hline 31662 & RT027 & Netherlands & Ed Kujiper \\
\hline DH478 & RT027 & Taunton, UK & Val Hall \\
\hline
\end{tabular}




\begin{tabular}{|c|c|c|c|}
\hline Dh482 & RT027 & Oxford, UK & Val Hall \\
\hline DH361 & RT027 & Lewisham, UK & Val Hall \\
\hline DH349 & RT027 & Cambridge, UK & Val Hall \\
\hline DH835 & RT027 & Birmingham, UK & Val Hall \\
\hline DH326 & RT027 & Sheffield UK & Val Hall \\
\hline DH131 & RT027 & Manchester, UK & Val Hall \\
\hline DH1329 & RT027 & Coventry, UK & Val Hall \\
\hline $\mathrm{DH} 1751$ & RT027 & Bradford, UK & Val Hall \\
\hline $\mathrm{DH} 1342$ & RT027 & Macclesfield, UK & Val Hall \\
\hline DH1858 & RT027 & Sunderland, UK & Val Hall \\
\hline R24694 & RT027 & Haverfordwest, UK & Val Hall \\
\hline R24988 & RT027 & Antrim, UK & Val Hall \\
\hline R23970 & RT027 & Ireland & Val Hall \\
\hline R12087 & RT027 & Unknown & Val Hall \\
\hline R20452 & RT027 & Canada & Val Hall \\
\hline R20298 & RT027 & USA & Val Hall \\
\hline CD2801 & RT027 & Nottinghamshire, UK & SBRC Nottingham \\
\hline CD5101 & RT027 & Nottinghamshire, UK & SBRC Nottingham \\
\hline CD9201 & RT027 & Nottinghamshire, UK & SBRC Nottingham \\
\hline CD3801 & RT078 & Nottinghamshire, UK & SBRC Nottingham \\
\hline CD4401 & RT078 & Nottinghamshire, UK & SBRC Nottingham \\
\hline CD8601 & RT078 & Nottinghamshire, UK & SBRC Nottingham \\
\hline CD9001 & RT078 & Nottinghamshire, UK & SBRC Nottingham \\
\hline CD9501 & RT078 & Nottinghamshire, UK & SBRC Nottingham \\
\hline CD9701 & RT078 & Nottinghamshire, UK & SBRC Nottingham \\
\hline CD9801 & RT078 & Nottinghamshire, UK & SBRC Nottingham \\
\hline CD1801 & RT078 & Nottinghamshire, UK & SBRC Nottingham \\
\hline Wilcox078 & RT078 & & Mark Wilcox \\
\hline
\end{tabular}




$\begin{array}{llll}\text { Type078 } & \text { RT078 } & \text { Leeds, UK } & \text { Ed Kujiper } \\ \text { CD2315 } & \text { RT078 } & \text { Hungary } & \text { Ed Kujiper } \\ 2016 & \text { RT078 } & \text { Ireland } & \text { Ed Kujiper } \\ 7004578 & \text { RT078 } & \text { Netherlands } & \text { Ed Kujiper } \\ 7009825 & \text { RT078 } & \text { Netherlands } & \text { Ed Kujiper } \\ 7045389 & \text { RT078 } & \text { Netherlands } & \text { Ed Kujiper } \\ \text { M120 } & \text { RT078 } & \text { Ireland } & \text { Brendan Wren } \\ \text { CD01027C1 } & \text { RT078 } & \text { Unknown } & \text { Nottingham } \\ \text { DH183 } & \text { RT106 } & \text { Leicester, UK } & \text { Val Hall } \\ \text { R10432 } & \text { RT106 } & \text { Bristol, UK } & \text { Val Hall } \\ \text { R12801 } & \text { RT106 } & \text { Bristol, UK } & \text { Val Hall } \\ \text { R15347 } & \text { RT106 } & \text { London, UK } & \text { Val Hall } \\ \text { R108095 } & \text { RT106 } & \text { Poole, UK } & \text { Val hall } \\ \text { R22079 } & \text { RT106 } & \text { Sheffield, UK } & \text { Val Hall } \\ \text { R23942 } & \text { RT106 } & \text { Cambridge, UK } & \text { Val Hall } \\ \text { R25469 } & \text { RT106 } & \text { Northern Ireland } & \text { Val Hall } \\ \text { R27384 } & \text { RT106 } & \text { Merthyr Tydfil, UK } & \text { Val Hall }\end{array}$


Table S2: List of primers for the closure of phage genomes

\begin{tabular}{|c|c|c|}
\hline Primer & Sequence 5'-3'- & $\begin{array}{l}\text { Description } \\
\text { (nucleotide } \\
\text { position) }\end{array}$ \\
\hline CD08011 parA1 & CGTATTAAGGCTTGTACTC & $\begin{array}{l}\text { Genome closure for } \\
\text { Ф08011 } \\
(20781-20799)\end{array}$ \\
\hline CD08011 pol1 & GCAAGAGCTGTTCATCAG & $\begin{array}{l}\text { Genome closure for } \\
\text { Ф08011 } \\
(22208-22225)\end{array}$ \\
\hline CD1801 portal1 & GCTGATATAGCTAGAAGACAAG & $\begin{array}{l}\text { Genome closure for } \\
\text { Ф1801 } \\
(1469-1490)\end{array}$ \\
\hline CD1801 portal2 & GACTTAGTTGCTATATCTGC & $\begin{array}{l}\text { Genome closure for } \\
\text { Ф1801 } \\
(3297-3316)\end{array}$ \\
\hline CD418 phage protein 1 & GGTCACATATAATTCTATTTG & $\begin{array}{l}\text { Genome closure for } \\
\text { Ф418 } \\
(24970-24990)\end{array}$ \\
\hline CD418 collar 1 & CGATTGATGAAGTTGTTAG & $\begin{array}{l}\text { Genome closure for } \\
\text { Ф418 } \\
(22851-22869)\end{array}$ \\
\hline
\end{tabular}




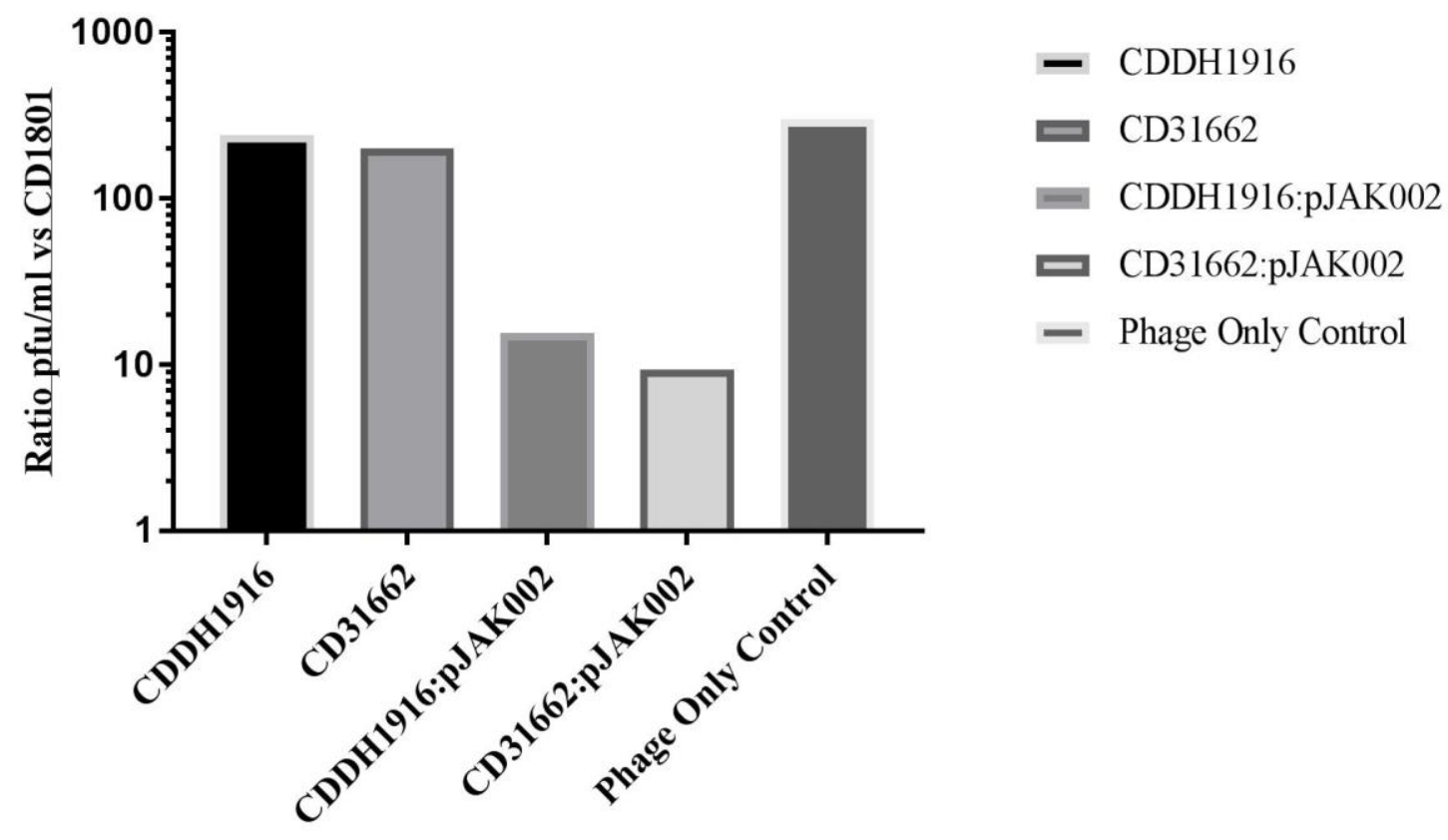

Figure S1: Phage binding is SLCT-dependent in RT 027. The capacity for CDDH1916 and CD31662 to bind to $\Phi C D 1801$ was assessed by means of a phage binding assay with wild-type parental strains and those harnessing plasmid-borne SLC H2/6 (pJK002) under the control of a tetracycline inducible promoter. Following co-incubation with wild-type or plasmid-bearing RT 027 strains, the titer of free $\Phi C D 1801$ particles was assessed through a plaque assay using the propagating strain CD18101 as an indicator. Data represent the mean of a single biological experiment and as such, statistical confidence cannot be obtained. 